\title{
Wybrane motywy biblijne z Ksiąg Jozuego \\ i Sędziów w Godzinkach o Niepokalanym Poczęciu Najświętszej Maryi Panny
}

Jednym z nabożeństw paraliturgicznych, z którym spotykamy się w życiu Kościoła, są Godzinki o Niepokalanym Poczęciu Najświętszej Maryi Panny. Za twórcę Godzinek w dzisiejszej formie uważa się Alfonsa Rodrigueza SI (1531-1617). Hymn tworzący rdzeń Godzinek, który wykorzystał Rodriguez, pochodzi z 1476 roku$^{1}$. W 1615 roku Godzinki zostały zatwierdzone przez Stolicę Apostolską, a w 1616 roku wydano je w Rzymie. Przekładu na język polski dokonał nieznany jezuita z krakowskiego kościoła św. Barbary około 1620 roku, a w 1625 roku ukazały się one drukiem². J. Domański pisze: „choć były one pochodzenia obcego, to przyswoiła je sobie dusza polska. Śpiewano je bardzo często i to nie tylko przed prymarią, ale też w pałacach i chatach, za pługiem i na polu bitwy"3. Zwyczaj śpiewania Godzinek jest kultywowany w wielu kościołach również w dobie współczesnej. Aktualnym problemem pozostaje więc kwestia rozumienia zawartych w tym nabożeństwie obrazów biblijnych ${ }^{4}$. Wydaje się bowiem, że są one nieczytelne dla współczesnego człowieka. Próba ich wyjaśnienia ma wobec tego charakter nie tylko teoretyczny, ale i praktyczny, duszpasterski. Celem niniejszego opracowania jest podkreślenie biblijnego bogactwa Godzinek oraz przy-

${ }^{1}$ Por. A. Klawek, Biblijne symbole maryjne, „Ruch Biblijny i Liturgiczny” 4-6 (1956), s. 224; J. Kopeć, Godzinki, [w:] Encyklopedia katolicka, t. 5, Lublin 1989, k. 1238-1240.

${ }^{2}$ Por. J. Kopeć, Godzinki, dz. cyt., k. 1239.

${ }^{3}$ J. Domański, Niepokalane Poczęcie Najśw. Maryi Panny, [w:] Gratia Plena. Studia teologiczne o Bogurodzicy, pr. zb. pod red. B. Przybylskiego, Poznań 1965, s. 212.

${ }^{4}$ Por. A. Klawek, Biblijne symbole maryjne, art. cyt., s. 225. 
bliżenie czytelnikowi ich treści. W tym przedłożeniu ograniczono się do omówienia trzech motywów: światło z Gabaon (Joz 10, 10-13); runo Gedeona (Sdz 6, 36-40); plastr miodu Samsona (Sdz 14, 1-11).

\section{Światło z Gabaon (Joz 10, 10-13)}

${ }^{10} \mathrm{~A}$ Pan napełnił ich strachem na sam widok Izraela i zadał im wielką klęskę pod Gibeonem. Ścigano ich w stronę wzgórza Bet-Choron i bito aż do Azeki i Makkedy. ${ }^{11}$ Gdy w czasie ucieczki przed Izraelem byli na zboczu pod Bet-Choron, Pan zrzucał na nich z nieba ogromne kamienie aż do Azeki, tak że wyginęli. I więcej ich zmarło wskutek kamieni gradowych, niż ich zginęło od miecza Izraelitów. ${ }^{12} \mathrm{~W}$ dniu, w którym Pan podał Amorytów w moc Izraelitów, rzekł Jozue w obecności Izraelitów: «Stań słońce, nad Gibeonem! I ty, księżycu, nad doliną Ajjalonu! $»^{13}$ I zatrzymało się słońce, i stanął księżyc, aż pomścił się lud nad wrogami swymi. Czyż nie jest to napisane w Księdze Sprawiedliwego: «Zatrzymało się słońce na środku nieba i prawie cały dzień nie spieszyło do zachodu?».

Wędrówka Izraelitów po pustyni zakończyła się wejściem do ziemi Kanaan. Na czele narodu izraelskiego stał wybrany przez Boga na następcę Mojżesza Jozue ${ }^{5}$. Głęboko wierzył w to, że Bóg opiekuje się Izraelem i pomoże zdobyć ziemię obiecaną - Kanaan 6 . Z wyraźnego rozkazu Boga Mojżesz wkłada ręce na Jozuego, proklamując go przez ten gest swoim następcą ${ }^{7}$ Jozue staje na czele wojsk izraelskich i odnosząc sukcesy militarne, zdobywa Kanaan ${ }^{8}$. W wielu z nich można zauważyć cudowną ingerencję Boga. Do jednej z takich interwencji nawiązują Godzinki. Mowa o wydarzeniach, które miały miejsce w czasie zdobywania Gibeonu'. W czasie walki o to miasto doszło do zjawiska zwanego popularnie „zatrzymaniem słońca” przez Jozuego. Zdarzenie to przedłużyło dzień i dało zwycięstwo Izraelitom. Autor Godzinek nawiązuje do niego poprzez zwrot: „Witaj światło z Gabaon, coś zwycię-

${ }^{5}$ Por. K. Pauritsch, Josua, [w:] Praktisches Bibel Lexikon, hrsg. von A. Grabner-Haider, Freiburg-Basel-Wien 1977, s. 593; J. Nelis, Josue, [w:] Bibel Lexikon, hrsg. von H. Haag, Leipzg 1969, s. 882-886; Jozue, [w:] H. Langkammer, Stownik biblijny, Katowice 1982, s. 81.

${ }^{6}$ Por. S. Łach, Księga Liczb, Poznań-Warszawa 1970, s. 150 (Pismo Święte Starego Testamentu, 2.2).

${ }^{7}$ Por. tamże, s. 241-243; M. Navarro Puerto, Księga Jozuego, Sędziów i Rut, tł. P. Rak, Kraków 1998, s. 45-50 (Rozumieć Stary Testament).

${ }^{8}$ Por. Jozue, [w:] F. Rienecker, G. Maier, Leksykon biblijny, przekł. D. Irmińska, Warszawa 2001, s. 329-331 (Prymasowska Seria Biblijna).

${ }^{9}$ W LXX „Gabaon”. 
stwo dało" ${ }^{10}$. Gdy mieszkańcy Gibeonu dowiedzieli się o klęsce Jerycha i Aj - pierwszych zdobytych przez Izraelitów miast na ziemi Kanaan, postanowili użyć podstępu. Przebrali się w zniszczone szaty i udając przybyszów z dalekiej krainy, przybyli do Jozuego, prosząc o zawarcie przymierza. Podstęp się udał i przymierze zostało zawarte. Jozue przysięgą zapewnił bezpieczeństwo ich życia i mienia. Poselstwo wróciło do Gibeonu, nie obawiając się klęski, którą mogli im zadać Izraelici. Wkrótce cała sprawa się wydała - okazało się, że przybysze „byli ludem sąsiednim i mieszkali wśród Izraela" (Joz 9, 16). Jozue pozostał jednak wierny złożonej przysiędze. Mieszkańcy Gibeonu zostali przeznaczeni do określonych posług, m.in. w świątyni „uczynił ich Jozue drwalami i noszącymi wodę dla całej społeczności i dla ołtarza Pańskiego" (Joz 9, 27). Kiedy książęta kanaanejscy dowiedzieli się o tym, że Gibeonici zawarli przymierze i pokój z Izraelitami, zorganizowali koalicję przeciw Gibeonowi i zaatakowali miasto. Mieszkańcy Gibeonu wezwali na pomoc Izraelitów, a ci od razu przystąpili do ataku i stoczyli bitwę w dolinie Ajjalon z wojskami pięciu królów. W czasie walki rozpętała się nadzwyczaj silna burza gradowa, która spowodowała straszliwy pogrom wśród uciekających wojsk amoryckich, „i więcej ich zmarło wskutek kamieni gradowych, niż ich zginęło od miecza synów Izraela" (Joz 10, 11b). Bóg jako Pan natury jest sprzymierzeńcem wojsk izraelskich ${ }^{11}$. Natchniony redaktor, opisując przebieg bitwy, przytoczył cytat z zaginionej poetyckiej Księgi Sprawiedliwego ${ }^{12}$, zbioru pieśni sławiących zwycięstwa bohaterów ${ }^{13}$ : „Wstań słońce nad Gibeonem. I ty, księżycu, nad doliną Ajjalonu! I zatrzymało się słońce, i stanął księżyc, aż pomścił się lud nad wrogami swymi" (Joz 10, 12-13). Wiersze te stanowią poetycki opis bitwy pod Gibeonem i są powtórzeniem przedstawionego wcześniej opisu walki w dolinie Ajjalon.

Prawie współczesny autorowi Księgi Jozuego Homer podobnie opisuje w Odysei, jak Pallas przedłuża noc Odyseuszowi i Penelopie: „I byliby

${ }^{10}$ Tekst Godzinek zob. J. Siedlecki, Śpiewnik kościelny, Kraków 2005², s. 704-710.

${ }^{11}$ Das Buch Josua, [w: Echter Bibel. Altes Testament, hrsg. von F. Nötscher, t. 3, Würzburg 1955, s. 582.

${ }^{12}$ Księga Sprawiedliwego cytowana jest jeszcze w 2 Sm 1, 18.

${ }^{13}$ E. S. Cetina, Księga Jozuego, [w:] Międzynarodowy komentarz do Pisma Świętego. Komentarz katolicki i ekumeniczny na XXI wiek, red. nauk. wyd. oryg. W. R. Farmer, red. nauk. wyd. pol. W. Chrostowski, Warszawa 2000, s. 444. 
kwilili do Jutrzenki złotej, lecz Pallas przedłużyła dla nich te pieszczoty. Bo okres nocy przeciągała i rydwan Eosy z Lampem i Faetonem nie wbiegł na niebiosy. Od brzegu oceanu ona go wstrzymała; I Eos blaski swoje nieprędko rozsiała" $(23,184-188)^{14}$. W Iliadzie można znaleźć opis cudownej interwencji Zeusa, który „przy kitach ciemne rozciągał obłoki”, aby Grecy mogli uratować siebie i wynieść z pola walki poległych ${ }^{15}$. Nikt nie bierze tych słów dosłownie. Również i poezję biblijną musimy inaczej oceniać i nie brać jej obrazowych wyrażeń jednoznacznie.

Do zwrotów, których nie należy rozumieć dosłownie, zalicza się wyrażenia: „zatrzymało się słońce” i „stanął księżyc”"16. Mogą one być użyte w odniesieniu do słońca i księżyca w znaczeniu „zaćmić się”, „przestać świecić” (por. Ha 3, 11; Ps 18, 8-16). Tego rodzaju zjawisko mogło mieć miejsce podczas silnej burzy gradowej, co z kolei dawało złudzenie zatrzymania się słońca. Dzięki tej specjalnej ingerencji Boga Jozue zyskał czas, bo dzień stał się jakby dwukrotnie dłuższy ${ }^{17}$. Były jeszcze inne próby tłumaczenia tego zjawiska. Sądzono, że zdarzyło się szczególnego rodzaju załamanie promieni słońca, tak że mogło ono już faktycznie zajść, lecz długo jeszcze trwały bardzo jasne wieczorne zorze. Mógł też przytrafić się upadek meteorytu połączony z nadzwyczajnym rozjaśnieniem nocy. Szukanie jednak wyjaśnień naukowych tekstu o zatrzymaniu się słońca nie jest rzeczą najważniejszą ${ }^{18}$. Nie wolno lekceważyć intencji autora, który chciał wyłącznie zaakcentować fakt, że Jahwe pomagał Izraelitom w walce ${ }^{19}$. Historyczna jest w tym opisie walka i zwycięstwo, a wzmianka o zatrzymaniu się słońca i księżyca ma charakter ekspresji literackiej ${ }^{20}$.

${ }^{14}$ Homer, Odyseja, Wrocław 1965, s. 368-369.

${ }^{15}$ Homer, Iliada, Wrocław 1950, s. 268.

${ }^{16}$ Z. Ziółkowski, Spotkanie z Biblia, Poznań 1971, s. 620-621

${ }^{17}$ S. Stańczyk, Księga Jozuego. Wstęp - tłumaczenie - komentarz, [w:] Pismo Święte Starego i Nowego Testamentu [Biblia Poznańska], oprac. zespół pod red. M. Petera, M. Wolniewicza, Poznań 1973, s. 386.

${ }^{18}$ M. Peter, Wykład Pisma Świętego Starego Testamentu, Poznań 1959, s. 225.

${ }^{19}$ Por. M. D. Coogan, Księga Jozuego, [w:] Katolicki komentarz biblijny, red. nauk. wyd. oryg. R. E. Brown, J. A. Fitzmyer, R. E. Murphy, red. nauk. wyd. pol. W. Chrostowski, Warszawa 2001, s. 195 (Prymasowska Seria Biblijna, 17).

${ }^{20}$ Por. H. W. Hersberg, Die Bücher Josua, Richter, Ruth, Göttingen 1973, 73-74 (Das Alte Testament Deutsch, 9); R . de Vaux, Histoire ancienne d'Israel, Paris 1971, 582 . 
Postać Jozuego przypomina nam Zbawiciela. Imię Jozue oznacza "Jahwe zbawia". Po śmierci Mojżesza Jozue zostaje wyznaczony przez Boga na wodza narodu wybranego (Lb 27, 11-23). Jozue był postacią wyróżniającą się, był wodzem w walce z Amalekitami (Wj 17, 8-16), wyszedł wraz z Mojżeszem na górę Synaj: „Wstał więc Mojżesz i Jozue, jego pomocnik, i wystąpił Mojżesz na górę Bożą" (Wj 24,13). Zawsze pozostawał przy boku Mojżesza, dlatego zwany był „sługą Mojżeszowym” (Wj 17, 9; Lb 11, 28).W ten sposób przygotowywał się do przyszłych zadań, które powierzył mu Bóg. Zasadniczym zadaniem było zdobycie ziemi Kanaan. Kiedy Mojżesz zgodnie z poleceniem Jahwe: „Weź Jozuego, syna Nuna, męża, w którym prawdziwie mieszka Duch i włóż na niego swoje ręce", włożył na niego ręce - Jozue otrzymał Ducha Bożego (Lb 27, 18).

Jozue jako wódz i głowa narodu wybranego wprowadził Izraelitów do ziemi Kanaańczyków, by ją wziąć w dziedzictwo. Aby ją zdobyć, musiał stoczyć wiele walk z książętami tej ziemi. Izraelici nie walczyli jednak sami - pomagał im Bóg. Jego działanie było widoczne, kiedy siły przyrody stanęły na usługi Izraela, jak np. w bitwie pod Gibeonem. Dzięki interwencjom Boga Jozue „zbawił wybranych Bożych” z ręki Kanaańczyków.Jest on jednak tylko bladym cieniem przyszłego Wybawcy, który też będzie nazwany tym samym imieniem „Jahwe zbawia”. Jezus Chrystus przez swoją śmierć, zmartwychwstanie i wniebowstąpienie dał prawdziwe zbawienie ludowi Bożemu.

Najświętsza Maryja Panna tak blisko związana z Chrystusem od chwili, gdy stanął przed Nią wysłannik Boży i oznajmił Jej, że została wybrana na Matkę Zbawiciela, była „światłem”; ,światłem”, które wskazywało ludziom, że Ten, którego ona jest Matką, dokona zbawienia - prawdziwego zwycięstwa, na które ludzkość z utęsknieniem oczekiwała od czasów Adama i Ewy. Pozwoliła zabłysnąć pełnym blaskiem temu „Światłu z Gabon, co zwycięstwo dało"21.

W zwycięstwie Jozuego dużą rolę odegrało przedłużenie dnia. W zwycięstwie Chrystusa nad szatanem i grzechem zasadniczą rolę odegrała Maryja - ona była Jego Matką, brała udział w misteriach odkupieńczych Chrystusa ${ }^{22}$. Sobór Watykański II uczy, że Maryja przy krzyżu „najgłębiej ze swym Jednorodzonym współcierpiała i z ofiarą Jego złączyła się

\footnotetext{
${ }^{21}$ Por. A. Tronina, Zawitaj, Pani świata, Niepokalanów 1995, s. 81.

${ }^{22}$ Por. W. Granat, Ku człowiekowi i Bogu w Chrystusie, t. 1, Lublin 1972, s. 503.
} 
matczynym duchem, z miłością godząc się, aby doznała ofiarniczego wyniszczenia żertwa z Niej zrodzona"23.

\section{Runo Gedeona (Sdz 6, 36-40)}

${ }^{36}$ Rzekł więc Gedeon do Boga: «Jeżeli naprawdę chcesz przeze mnie wybawić Izraela, jak to powiedziałeś, ${ }^{37}$ pozwól, że położę runo wełny na klepisku; jeżeli rosa spadnie tylko na runo, a cała ziemia dokoła będzie sucha, będę wiedział, że wybawisz Izraela przeze mnie, jak powiedziałeś». ${ }^{38}$ Tak uczynił. Kiedy rano wstał $\mathrm{s}$ ścisnął wilgotne runo, wycisnął z runa pełną czaszę wody. ${ }^{39}$ I rzekł Gedeon do Boga: «Nie gniewaj się na mnie, jeżeli przemówię jeszcze raz do ciebie. Pozwól, że jeszcze raz powtórzę doświadczenie z runem: niech rano będzie suche tylko samo runo, a niech na ziemi dokoła będzie rosa». ${ }^{40}$ I Bóg sprawił to tej nocy: samo runo pozostało suche, a na ziemi była rosa.

Po długoletnich walkach pod przewodnictwem Jozuego Izraelici zdobyli ziemię Kanaan. Będący już w podeszłym wieku Jozue otrzymał wtedy polecenie od Boga, by podzielić kraj między poszczególne plemiona Izraela (Joz 13-19). Posłuszny Bogu wykonał to zadanie. Jozue, czując swoją bliską śmierć, nawoływał do wierności wobec Boga. Zwołał cały lud, aby mu przypomnieć o tym, co Izrael zawdzięcza swemu Panu. Po raz drugi Jozue przemówił w Sychem - tam zwołał lud i jego przełożonych, by im przedstawić dzieje Izraela począwszy od czasów Abrahama. Ponownie napominał wszystkich, by pozostali wierni Bogu. Niedługo potem Jozue umarł (Joz 23-24).

Przez pewien czas lud był wierny Bogu, pamiętał o wielkich dobrodziejstwach, jakie mu On uczynił (Sdz 2, 6-9). Wkrótce jednak synowie Izraela zaczęli czynić to, co „złe w oczach Jahwe i służyli Baalom” (Sdz $2,11)$. Przez to sprowadzili na siebie gniew Boga, zostali wydani na ucisk i na łup nieprzyjaciół. Bóg nie odszedł od swego narodu, któremu dał ziemię Kanaan, a wcześniej wyzwolił z Egiptu. Powołał specjalnych mężów zwanych „sędziami”, których zadaniem było rządzić ludem izraelskim, bronić czystości wiary i wolności politycznejej ${ }^{24}$

${ }^{23}$ Sobór Watykański II, konst. Lumen gentium, 58.

${ }^{24}$ Por. Sąd, [w:] L. Ryken, J. C. Wilhoit, T. Longman, Słownik symboliki biblijnej. Obrazy, symbole, motywy, metafory, figury stylistyczne i gatunki literackie w Piśmie Świętym, przekł. Z. Kościuk, Warszawa 2003, s. 892 (Prymasowska Seria Biblijna, 20). 
Jednym z „sędziów” rządzących narodem izraelskim był Gedeon ${ }^{25}$. Każdego „sędziego” Bóg powoływał osobiście. Gedeon upewnił się o swym posłannictwie przez cud z runem owczym (ó đókoৎ) zwanym inaczej „runem Gedeona” ${ }^{26}$. W Księdze Sędziów jest mowa o 12 „sędziach". Otoniel, Ehud, Borah, Gedeon, Jefte i Samson zwani byli „sędziami większymi", natomiast Tola, Jair, Szamgar, Ibson, Elon i Abdon są nazywani „sędziami mniejszymi”.

Do grupy wybitnych „sędziów” należy Gedeon, który pochodził z pokolenia Manassesa ${ }^{27}$. Po zwycięstwie Debory nad Kanaanitami (Sdz 4, 1-22) Izrael pozostał przez pewien czas wierny Bogu. Wkrótce jednak na nowo popadł w bałwochwalstwo, tak że Bóg zesłał nań nowy ucisk. Madianici, z którymi walczyli Izraelici już za życia Mojżesza (Lb 31, 1-12), zaczęli napadać na ziemie Izraela. Wypasali swoimi wielbłądami i owcami pastwiska oraz zasiewy izraelskie, zagarniali także ich trzody. To spustoszenie kraju spowodowało wzmożenie błagalnych modlitw do Jahwe. Bóg, wysyłając Anioła, powołał Gedeona ${ }^{28}$ : „I ukazał mu się Anioł Pański. Pan jest z tobą - rzekł mu - dzielny wojowniku" (Sdz 6, 12). Ten prosi o znak, aby upewnić się o boskiej tożsamości swego rozmówcy i pomocy Bożej podczas toczonych walk ${ }^{29}$. Pewność taką daje Bóg albo poprzez sny (Sdz 7, 9-15), albo przez namacalne znaki, jak te, o które poprosił Gedeon ${ }^{30}$. Tym podwójnym znakiem były runo i rosa ${ }^{31}$. Runo wełniane, które służyło ludziom Wschodu za ubranie lub przykrycie (Sdz 4,18), miało nasiąknąć wodą bardziej niż ziemia. Rosa przychodzi „z nieba” (Pwt 33, 13), daje ulgę ciałom i duszom w gorącym okresie żniw.

Pierwszy znak polega na tym, że runo jest nasycone rosą, podczas gdy ziemia pozostaje sucha, a Gedeon wyciska wodę z runa i napełnia nią

${ }^{25}$ Por. G. Herrgott, Gideon-Jerubbaal, [w:] Praktisches Bibel Lexikon, dz. cyt., s. 420-421; A. van den Born, Gideon, [w:] Bibel Lexikon, dz. cyt., s. 589-590; Gedeon, [w:] H. Langkammer, Słownik biblijny, dz. cyt., s. 61.

${ }^{26}$ Por. M. Navarro Puerto, Księga Jozuego, Sędziów i Rut, dz. cyt., s. 115-117.

${ }^{27}$ Por. Gedeon, [w:] F. Rienecker, G. Maier, Leksykon biblijny, dz. cyt., s. 244-245.

${ }^{28}$ Por. F. Nötscher, Das Buch der Richter, [w:] Echter Bibel, Altes Testament, hrsg. von F. Nötscher, t. 3, Würzburg 1955, s. 648-649; por. Łk 1, 28.

${ }^{29}$ Por. Wetna, [w:] L. Ryken, J. C. Wilhoit, T. Longman, Słownik symboliki biblijnej..., dz. cyt., s. 1075.

${ }^{30}$ Por. M. O'Connor, Księga Sędziów, [w:] Katolicki komentarz biblijny, dz. cyt., s. 224.

${ }^{31}$ Por. H. W. Hersberg, Die Bücher Josua, Richter, Ruth, dz. cyt., s. 194. 
czaszę $^{32}$. Po krótkim namyśle prosi o jeszcze jeden znak, bardziej przekonywujący, gdyż wschodzące słońce mogło bardzo dobrze wysuszyć ziemię, a gęste runo wełniane pozostało nadal przesycone rosą. Gedeon zwraca się z wielkim szacunkiem do Boga, prosząc by zaszło zjawisko przeciwne: runo suche, a ziemia pokryta rosą. Tym razem będzie to znak niewątpliwy, dostrzegalny dla wszystkich - Jahwe chce przez Gedeona uwolnić Izrael. Bóg wysłuchuje modlitwy Gedeona, udziela mu swojej łaski³. Gedeon prosi Boga w dobrej woli, jego zachowanie jest zgodne z mentalnością ówczesnych, nie zachodzi więc potrzeba usprawiedliwienia go z tego, że kusił Boga ${ }^{34}$. Gedeon posłuszny Bogu ogranicza do trzystu liczbę swoich żołnierzy mających walczyć z Madianitami. Z tą garstką uderza na Madianitów i odnosi zwycięstwo. Madianici w popłochu opuszczają ziemie izraelskie. To wydarzenie ukazuje, że zwycięstwa nad wrogami odnosi się nie tyle przy pomocy ludzkich sił, strategii, ile dzięki temu, że Bóg błogosławi naszym, choćby najmniejszym wysiłkom ${ }^{35}$. Zwycięstwo Gedeona było jednym z najwspanialszych w historii Izraela. Ofiarowano mu godność królewską, której jednak nie przyjął, mówiąc: „Nie ja będę panował nad wami ani też mój syn, Jahwe będzie panował nad wami” $(\mathrm{Sdz} 8,23)$. Gedeon spełniał władzę sędziowską przez czterdzieści lat.

Autor Godzinek, nawiązując do znaku, o który prosi Gedeon, porównuje Maryję do „runa Gedeona” ${ }^{36}$. Cudowność wyjątku, jakiego dokonał Bóg z runem, nasycając go rosą, to znów zostawiając go suchym, jest obrazem Najświętszej Maryi Panny. Jest symbolem jej niepokalanego poczęcia, czyli również cudownego wyjątku dokonanego przez wszechmoc Bożą. Spośród wszystkich ludzi tylko Maryja nie została splamiona grzechem. Nazywa się Ją „Bezgrzeszną”, a św. Łukasz w swojej Ewangelii notuje słowa wysłannika Bożego, które potwierdzają Jej bezgrzeszność: „Bądź pozdrowiona, pełna łaski, Pan z Tobą” (Łk 1, 28) 37.

${ }^{32}$ Por. F. Nötscher, Das Buch der Richter, dz. cyt., s. 651.

${ }^{33}$ Por. Wetna, [w:] L. Ryken, J. C. Wilhoit, T. Longman, Słownik symboliki biblijnej..., dz. cyt., 874-875.

${ }^{34}$ Por. A. Gelin, Le livres des Juges, Paris 1949, s. 207-208 (Le Saint Bibie, 3).

${ }^{35}$ T. L. J. Mafico, Księga Sędziów, [w:] Międzynarodowy komentarz do Pisma Świętego, dz. cyt., s. 465.

${ }^{36}$ Por. A. Tronina, Zawitaj, Pani świata, dz. cyt., s. 46-47.

${ }^{37}$ Por. F. Bovon, Das Evangelium nach Lukas, Zürich-Neukirchen-Vluyn 1989, s. 7374 (Evangelisch-Katholischer Kommentar zum Neuen Testament, 3.1); W. Radl, Das 


\section{Plastr miodu Samsona (Sdz 14, 1-11)}

${ }^{1}$ Samson zstąpił do Timny i ujrzał tam kobietę wywodzącą się z córek filistyńskich. ${ }^{2}$ Wróciwszy, tak oznajmił swemu ojcu i matce: «W Timnie ujrzałem wśród córek filistyńskich pewną kobietę. Weźcie mi ją teraz za żonę!» ${ }^{3}$ Rzekł mu jego ojciec i matka: «Czyż nie ma kobiety pomiędzy córkami twoich braci i w całym twoim narodzie, żeś poszedł szukać żony wśród nieobrzezanych Filistynów?» Samson odpowiedział swemu ojcu: «Weźcie mi tę, gdyż spodobała się moim oczom». ${ }^{4}$ Rodzice jego nie wiedzieli, że to pochodziło od Pana, który szukał słusznego powodu do sporu z Filistynami, albowiem Filistyni panowali w tym czasie nad Izraelitami. ${ }^{5}$ Udał się więc Samson wraz z ojcem swoim i matką do Timny, a gdy się zbliżał do winnic Timny, oto młody lew, rycząc, stanął naprzeciw niego. ${ }^{6}$ Wówczas opanował go duch Pana, tak że lwa rozdarł, jak się koźlę rozdziera, chociaż nie miał nic w ręku. Jednak nie zdradził się wobec swego ojca i matki z tego, co uczynił. ${ }^{7}$ Kiedy przyszedł na miejsce, rozmawiał z ową kobietą i spodobała mu się. ${ }^{8}$ Gdy po jakimś czasie Samson wracał, by wziąć ją za żonę, zboczył, by obejrzeć padlinę lwa, a oto rój pszczół i miód znalazły się w padlinie. ${ }^{9}$ Wziął go więc do ręki i jadł, a gdy przyszedł do swego ojca i matki, dał im także, aby jedli, nie mówiąc im jednak, że miód zebrał z padliny lwa. ${ }^{10}$ Następnie jego ojciec poszedł do owej kobiety i sprawiono Samsonowi wesele, które trwało siedem dni, bo taki mieli zwyczaj młodzieńcy. ${ }^{11}$ Ponieważ jednak obawiano się go, wybrano trzydziestu towarzyszy, którzy przy nim byli.

Samson podobnie jak Gedeon był jednym z „sędziów” izraelskich ${ }^{38}$. Pochodził z pokolenia Dan, z miejscowości Sorea (Sdz 13, 1-25). Wsławił się w walkach przeciw Filistynom (Sdz 15, 1-16). Władzę „sędziego" sprawował dwadzieścia lat (Sdz 15, 20). Jego biografia obfituje w cudowne wydarzenia. Już narodzenie poprzedzone było nadzwyczajnymi okolicznościami - zwiastowaniem, ofiarą złożoną przez Manoacha, ojca Samsona (13,1-23). Żona Manoacha była kobietą niepłodną, nie wydała na świat potomka. Gdy Izraelici wskutek swego złego postępowania popadli w niewolę filistyńską, Jahwe wysłał swego anioła do Sorei, żony Manoacha, by jej oznajmić, że choć dotychczas nie rodziła, stanie się matką chłopca ${ }^{39}$. Chłopiec ten będzie Bożym nazirejczykiem obdarzonym przez Boga niezwykłą siłą fizyczną, sprytem i przebiegłością (Sdz 13,

Evangelium nach Lukas, t. 1, Freiburg-Basel-Wien 2003, s. 60-61.

${ }^{38}$ Por. L. Thum, Simson, [w:] Bibel Lexikon, dz. cyt., s. 1593-1594; A. Baum, Simson, [w:] Praktisches Bibel Lexikon, dz. cyt., s. 1011; Samson, [w:] L. Ryken, J. C. Wilhoit, T. Longman, Słownik symboliki biblijnej..., dz. cyt., 890-891; Samson, [w:] F. Rienecker, G. Maier, Leksykon biblijny, dz. cyt., s. 720-721; Samson, [w:] H. Langkammer, Słownik biblijny, dz. cyt., s. 104.

${ }^{39}$ Por. T. L. J. Mafico, Księga Sędziów, dz. cyt., s. 468. 
$5)^{40}$. Zewnętrzną oznaką wyboru przez Boga były nieobcinane od urodzenia włosy. W tych nieobcinanych włosach tkwiła jego nadzwyczajna siła: „Głowy mojej nie dotknęła nigdy brzytwa, albowiem od łona matki jestem Bożym nazirejczykiem. Gdyby mnie ogolono, siła moja odejdzie, osłabnę i stanę się zwykłym człowiekiem" (Sdz 16, 17).

Gdy Samson podrósł, spodobała mu się kobieta filistyńska, którą zobaczył w Timnie. Zwrócił się do rodziców z prośbą, by pozwolili mu pojąć ją za żonę. Ci początkowo sprzeciwiali się, bo nie chcieli ożenić syna z kobietą filistyńską wywodzącą się z wrogiego narodu, potem jednak ulegli synowi i udali się z nim do opanowanej przez Filistynów Timny (Sdz 14, 3). W drodze Samson stoczył walkę z lwem, z którym rozprawił się, jakby miał do czynienia z koźlęciem. Dokonał tego wyczynu dzięki „duchowi Jahwe” (Sdz 14, 6), który napełnił go nadzwyczajną siłą ${ }^{41}$. Następnie Samson spotkał się z ową kobietą i ponownie wrócił do domu rodzinnego. Po pewnym czasie, idąc ponownie do Timny, aby poślubić ukochaną przez siebie kobietę, Samson zboczył z drogi i poszedł zobaczyć padlinę lwa. Tam znalazł już tylko jego szkielet.

Słońce, szakale i ptactwo przyczyniło się do szybkiego zniknięcia ciała. W wysuszonym szkielecie lwa osiadł dziki rój pszczół. Może to trochę dziwne miejsce osiedlania się tych owadów, ale nie wydaje się niemożliwe. W starożytności w Izraelu nie prowadzono hodowli pszczół, jak to robili Hetyci, ale miód dzikich pszczół był ogromnie ceniony i łącznie $\mathrm{z}$ mlekiem charakteryzował bogactwo $\mathrm{kraju}^{42}$. O miodzie mówią również

${ }^{40}$ Nazirejczyk (hebr. nazir - poświęcony, wybrany) - człowiek wybrany przez Boga, zobowiązany do przestrzegania dodatkowych przepisów określonych w Prawie (Sdz 13, 5.14; 1Sm 1,11). Nazireat - nazwa ślubu składanego przez niektórych Izraelitów, który polegał na powstrzymywaniu się przez pewien określony czas od strzyżenia włosów, picia wina i na spełnianiu określonych w Księdze Liczb $(6,1-21)$ praktyk religijnych.

${ }^{41}$ Por. F. Nötscher, Das Buch der Richter, dz. cyt., s. 678.

${ }^{42}$ Por. Miód, [w:] L. Ryken, J. C. Wilhoit, T. Longman, Słownik symboliki biblijnej..., dz. cyt., 527-528; Miód, [w:] Słownik tła Biblii, red. nauk. wyd. oryg. J. I. Packer, M. C. Tenney, red. nauk. wyd. pol. W. Chrostowski, Warszawa 2007, s. 399-400 (Prymasowska Seria Biblijna, 26); F. H. Wight, Obyczaje krajów biblijnych, tł. R. Piotrowski, Warszawa 1998, s. 45-46; Miód, [w:] H. Langkammer, Słownik biblijny, Katowice 1982, s. 104; K. Pauritsch, Milch u. Honig, [w:] Praktisches Bibel Lexikon, dz. cyt., s. 755; H. Haag, Das Land der Bibel, Stuttgart 2000, s. 43. 52. 
inne księgi Pisma Świętego ${ }^{43}$. Występuje on jako środek do słodzenia pokarmów, stąd pochodzą powiedzenia: „Słodki jak miód” (Ez 3, 3); „Pamięć o mnie jest słodsza nad miód, a posiadanie mnie - nad plaster miodu” (Syr 24, 20); „Cenniejsze niż złoto, niż złoto najczystsze, a słodsze od miodu płynącego z plastra" (Ps 19,11) ${ }^{44}$. Miód uważany jest także za wyjątkowy przysmak: „Śmietanę i miód spożywać będzie” (Iz 7, 15a) ${ }^{45}$.

Samson, gdy zobaczył miód ( (ò $\mu \varepsilon ́ \lambda_{1}$ ), zaczął go jeść. Zaniósł go też swoim rodzicom, aby i oni zjedli (Sdz 14,9 9) ${ }^{46}$. Nie powiedział im nic o pochodzeniu miodu. Milczenie to było podyktowane późniejszą zagadką zadaną Filistynom w trakcie trwania wesela. Zagadka brzmiała: „Z tego, który pożera wyszło to, co się spożywa; a z mocnego wyszła słodycz" (Sdz 14, 14). Filistyni nie potrafili jej rozwiązać ${ }^{47}$. Poprosili żonę Samsona, aby ta dowiedziała się, jakie jest jej rozwiązanie. Samson uległ jej natrętnym pytaniom i zdradził rozwiązanie zagadki. Ona z kolei podała to rozwiązanie synom swego narodu, którzy przekazali je Samsonowi: „Cóż słodszego niż miód, a cóż mocniejszego niż lew" (Sdz 14, 18) ${ }^{48}$. Samson zrozumiał, że został zdradzony przez swoją żonę, opuścił ją i udał się do domu swego ojca. Gdy po kilku dniach przyszedł odwiedzić żonę, dowiedział się od jej ojca, że już została oddana innemu mężczyźnie za małżonkęa9. Od tej chwili Samson rozpoczął walkę z Filistynami.

Filistyni zamieszkiwali urodzajną, wydającą obfite plony ziemię Szefela. Gdy przygotowywali się do zebrania dojrzałego zboża ze swoich pól, Samson postanowił zniszczyć ich zasiewy. Nałapał trzysta lisów (Sdz 15, 4) i przy ich pomocy pochodniami podpalił zboże, winnice i gaje oliwne. Taki był wówczas zwyczaj prowadzenia wojny - bez miłosierdzia pustoszono ziemię nieprzyjacielską, żeby wygłodzić jej mieszkańców (Sdz 6, 3-4) s0. $^{50}$.

Samson udał się następnie do groty w Etam, Filistyni zaś wkroczyli na ziemie pokolenia Judy, aby go pojmać. Wtedy mieszkańcy Judy

${ }^{43}$ Por. J. J. Pilch, Słownik kultury biblijnej, tł. M. Zamora, B. Śliwińska, Częstochowa 2004, s. 101; A. Born, Honig, [w:] Bibel Lexikon, dz. cyt., s. 759-760.

${ }^{44}$ Por. Syr 49, 1; Ps 119, 103; Ap 10, 9-11.

${ }^{45}$ Por. 1 Sm 14, 25-27; 2 Sm 17, 29.

${ }^{46}$ Por. Pwt 32, 13; 1 Sm 14, 25-27; Ps 81, 17; Mt 3, 4 i paralelne.

${ }^{47}$ Por. H. W. Hersberg, Die Bücher Josua, Richter, Ruth, dz. cyt., s. 229-230.

${ }^{48}$ Por. A. Tronina, Zawitaj Pani świata, dz. cyt., s. 48-49.

${ }^{49}$ Por. tamże, s. 230-231.

${ }^{50}$ Por. F. H. Wight, Obyczaje krajów biblijnych, dz. cyt., s. 254-255. 
przyszli licznie do groty w Etam, aby wydać Samsona Filistynom. Samson dał się im związać i zaprowadzono go przed wojska filistyńskie. Gdy usłyszał triumfalne okrzyki Filistynów, uwolnił się, potargawszy powrozy, którymi był związany i znalezioną oślą szczęką rozgromił Filistynów ${ }^{51}$. Po tym czynie Samson sprawował sądy nad Izraelem przez okres dwudziestu lat (Sdz 15, 8-20).

Sukcesy, które odnosił nad Filistynami, zostały zahamowane przez miłość do kobiety imieniem Dalila, która mieszkała w dolinie Sorek $(\mathrm{Sdz} 16,4)$. Przychodzili do niej władcy filistyńscy, prosząc ją, by dowiedziała się, w czym tkwi siła Samsona, ponieważ chcieli go zgładzić. Samson trzykrotnie wprowadzał Dalilę w błąd, w końcu jednak zdradził jej tajemnicę swej siły, oznajmiając, że pochodzi ona z jego niestrzyżonych włosów (Sdz 16, 5-21) 52. Dalila, gdy dowiedziała się o tym, kazała ostrzyc głowę śpiącego Samsona i wydała go w ręce Filistynów, którzy związawszy go łańcuchem, wyłupili mu oczy i zamknęli w więzieniu. Samsonowi przebywającemu długi czas w więzieniu włosy zaczynały odrastać. Przyprowadzony z więzienia na salę biesiadną, gdzie miał zabawiać ucztujących, prosił Boga, by mu jeszcze raz przywrócił dawną moc $^{53}$. Samson ujął słupy, na których wspierał się dom, zatrząsł nim i dom runął, grzebiąc Samsona oraz zebranych Filistynów. Zemsta była więc przyczyną śmierci Samsona ${ }^{54}$.

Z opowiadań związanych z Samsonem wypływa głęboki religijno-moralny sens: niepohamowana namiętność niszczy największą siłę, a niekwestionowanemu bohaterowi, który jako poświęcony Bogu do wielkich rzeczy był powołany, przynosi śmierć i upadek ${ }^{55}$. To, co stało się z Samsonem, było nauką i zachętą dla Izraelitów, by porzucili grzechy i trwali przy Bogu jako przy jedynym prawdziwym wybawcy i królu ${ }^{56}$.

${ }^{51}$ Por. M. O'Connor, Księga Sędziów, [w:] Katolicki Komentarz biblijny, dz. cyt., s. 230.

${ }^{52}$ Por. Włosy, [w:] L. Ryken, J. C. Wilhoit, T. Longman, Słownik symboliki biblijnej..., dz. cyt., s. 1108-1109.

${ }^{53}$ Por. M. O'Connor, Księga Sędziów, dz. cyt., s. 231.

${ }^{54}$ Por. Zemsta, [w:] L. Ryken, J. C. Wilhoit, T. Longman, Słownik symboliki biblijnej..., dz. cyt., s. 624.

${ }^{55}$ Por. T. L. J. Mafico, Księga Sędziów, dz. cyt., s. 468; J. Jelito, Historia czasów Starego Testamentu, Poznań-Warszawa 1961, s. 180-181.

${ }^{56}$ Por. M. Peter, Wykład Pisma Świętego, Poznań 1959, s. 233-234. 
Autor „Godzinek”, nawiązując do jednej ze scen z życia Samsona - zabicia lwa i znalezienia po pewnym czasie w jego szkielecie miodu ( $\mathrm{Sdz}$ 14, 5-11), dokonał porównania Maryi do ,plastra miodu”. Biorąc to pod uwagę, można prawdopodobnie widzieć w plastrze symbol Maryi, w miodzie - Chrystusa. Z Maryi dzięki wszechmocy Boga narodził się Jezus, który jest najlepszym pokarmem, jakby pewnego rodzaju „słodyczą”, bo pozostał w Eucharystii. Maryja karmi Jezusem, który jest Zbawicielem. Przyjście Jezusa na świat było zagadką dla ludzi oczekujących Jego narodzenia. Maryja przez swoje „tak” rozwiązała ją dla wszystkich pokoleń ludzkich. „Tyś plastr miodu Samsona” - jest to obraz Matki Najświętszej, który autor „Godzinek” nakreślił na tle życia jednego z „sędziów” Izraela.

Trzy scharakteryzowane teksty biblijne pozwalają dostrzec wielkie bogactwo teologiczne Godzinek. Można stwierdzić, że ich autor trafnie odniósł je do Najświętszej Maryi Panny. Maryja jest „światłem z Gabaon”, które wskazywało ludziom, że Ten, którego ona jest Matką, dokona zbawienia - prawdziwego zwycięstwa oczekiwanego od czasów Adama i Ewy. Maryja jest też „runem Gedeona”, bo Bóg dokonał w niej cudownego wyjątku - spośród wszystkich ludzi tylko ona nie została splamiona grzechem. Maryja jest „plastrem miodu”, gdyż z niej narodził się Ten, który jest naszym najlepszym pokarmem, który jest Zbawicielem ${ }^{57}$. Opole

KS. KRYSTIAN ZIAJA

\section{Słowa kluczowe}

Godzinki o Niepokalanym Poczęciu Najświętszej Maryi Panny, Najświętsza Maryja Panna, Eucharystia, Jozue, Gedeon, Samson, sędzia, światło, runo, wełna, miód, zwycięstwo, pokarm

${ }^{57}$ Maryja jest także „tęczą” (Rdz 9, 8-17); „krzakiem Mojżesza” (Wj 3, 2); „Arką Przymierza” (Wj 25, 10); „różdżką Aarona” (Lb 17, 16-26); „gwiazdą z Jakuba” (Lb 24, 17). 


\section{Summary}

\section{Biblical motives from the Book of Joshua and Book of Judges in the Hours about the Immaculate Conception of the Most Holy Virgin Mary}

The aim of the article is better understanding of the Hours concerning the Immaculate Conception of the Most Holy Virgin Mary. Following motives from the books of Joshua and Judges were taken into consideration: The light from Gabaon (Joshua 10, 10-13), Gedeon's fleece (Judges 6, 36-40), Samson's honeycomb (Judges 14, 1-11). After the discussion of the above mentioned three texts we may ascertain that the author of Hours about the Immaculate Conception of the Most Holy Virgin Mary with accurate aim refers the texts to the Most Holy Virgin Mary. Mary is the light from Gabaon, which showed people that he, whose mother she is, will make a salvation, the real victory that had been expected since Adam and Eve's times. Moreover, she is the fleece of Gedeon because God made her a wonderful exception as among people only she was not stained by a sin. Furthermore, she is Samson's honeycomb as inside her the one who is our Savior and our best food was born.

\section{Keywords}

Hours about the Immaculate Conception of the Most Holy Virgin Mary, The Most Holy Virgin Mary, Eucharist, Joshua, Gedeon, Samson, judge, light, fleece, wool, honeycomb, victory, food 